\title{
IDENTIFIKASI BORAKS PADA KETUPAT JANUR DI PASAR SEGAMAS KABUPATEN PURBALINGGA
}

\author{
Nindita Apri Herawati ${ }^{1}$, Agus Subagiyo ${ }^{1)}$ \\ 1) Jurusan Kesehatan Lingkungan, Poltekkes Kemenkes Semarang
}

\begin{abstract}
Abstrak
Latar belakang masalah berdasarkan data survei pendahuluan ditemukan beberapa ketupat janur yang dijual di Pasar Segamas diduga mengandung boraks. Fungsi sebenarnya dari boraks yaitu untuk bahan antiseptik, pengawet, dan anti jamur kayu, serta pembasmi kecoa. Penelitian ini bertujuan untuk mengidentifikasi ada tidaknya boraks pada ketupat janur yang dijual di Pasar Segamas Kabupaten Purbalingga. Metode penelitian yang digunakan adalah jenis penelitian deskriptif, dengan tujuan untuk mengetahui ada tidaknya kadar boraks pada ketupat janur yang dijual di Pasar Segamas Kabupaten Purbalingga. Penelitian ini dilakukan dengan pengumpulan data di lapangan dan pemeriksaan di Laboratorium kemudian bandingkan dengan Permenkes RI Nomor 033 Tahun 2012 tentang Bahan Tambahan Pangan. Hasil pemeriksaan laboratorium menunjukkan 6 sampel negatif boraks. Pemeriksaan secara organoleptik dihasilkan sampel ketupat 1 dan 2 dalam kondisi baik sedangkan sampel yang lain diduga mengandung boraks. Pengetahuan pedagang menunjukkan sebagian besar masuk kategori baik dengan nilai $83 \%$ dan $17 \%$ dalam kategori tidak baik. Pengawasan bahan tambahan pangan berbahaya di Pasar Segamas termasuk kategori sesuai Peraturan Bersama Menteri Dalam Negeri Dan Kepala Badan Pengawas Obat Dan Makanan Republik Indonesia Nomor : 2 dan Nomor : 43 Tahun 2013 Tentang Pengawasan Bahan Berbahaya Yang Disalahgunakan Dalam Pangan. Simpulan penelitian ini yaitu $100 \%$ ketupat janur negatif menggunakan boraks.
\end{abstract}

Kata Kunci: Boraks; Kesehatan Lingkungan; Ketupat Janur

\begin{abstract}
[Identification Of Borax In Rhombus At Segamas Market Purbalingga Regency Years 2020] Background of the problem based on preliminary survey data it was found that some rhombus shells sold in the segamas market were thought to contain borax. The actual function of borax is for antiseptic, preservative, and antifungal properties. The purpose of research to identify the presence or absence of borax in rhombus that is sold at the Segamas Market Purbalingga Regency. The research method used is descriptive research, with the aim to find out whether or not the levels of borax in rhombus are sold at Segamas Market, Purbalingga Regency. This research was conducted by collecting data in the field and examinations in the laboratory then compared with the Regulation of Health Minister Indonesia Number 033 of 2012 concerning Food Additives. The result laboratory tests showed that there are 6 of sample that negative from borax test. Organoleptic examination result in rhombus samples 1 and 2 in good condition while other samples are considered to contain borax. Traders' knowledge shows that most of them are in the good category with $83 \%$ and $17 \%$ in the bad category. The Supervision of hazardous food additives at the Segamas Market is included in the category according to Joint Regulation of the Minister of Home Affairs and Head of the Republic of Indonesia Drug and Food Control Agency Number: 2 and Number: 43 of 2013 about Supervision of Hazardous Substances Abused in Food. The conclusion of this research is 100\% negative rhombus using borax.
\end{abstract}

Keywords: Borax; Rhombus; Environmental Health 


\section{Pendahuluan}

Peranan Bahan Tambahan Pangan (BTP) atau yang sering disebut Bahan Tambahan Makanan (BTM) bertujuan membuat makanan tampak lebih berkualitas, lebih menarik, dengan rasa dan tekstur lebih sempurna.

Berdasarkan Peraturan Menteri Kesehatan Republik Indonesia Nomor 033 tahun 2012 tentang Bahan Tambahan Pangan, boraks merupakan bahan tambahan yang dilarang digunakan dalam makanan karena pada kadar tertentu boraks sangat berbahaya apabila berada dalam tubuh manusia. Boraks secara lokal dikenal sebagai air bleng, garam bleng atau pijar. Disamping itu, boraks ternyata digunakan untuk industri makanan lain, seperti dalam pembuatan mie, lontong, ketupat, bakso, bahkan juga untuk pembuatan kecap (F.G. Winarno dan Ir. Titi Sulistyowati Rahayu. 1994. h. 105).

Menurut penelitian Rizki Amelia (2013) yang dilakukan di Pasar Raya Padang dengan sampel lontong, dari 10 sampel lontong yang diambil secara random didapatkan tidak ada satupun sampel lontong yang mengandung boraks. Penelitian yang dilakukan oleh Siti Istiqomah (2016) hasil pengujian kualitatif menunjukkan 165 sampel $(100 \%)$ yang diambil dari pedagang bakso dan tempat penggilingan tidak menggunakan boraks. Ummi Salamah Lubis (2015) juga melakukan penelitian tentang boraks pada lontong dengan jumlah sampel 15 lontong, hasil penelitian menunjukkan bahwa terdapat lontong yang mengandung boraks dengan kadar 1140 ppm dalam 1 $\mathrm{kg}$ adonan lontong dan penelitian yang dilakukan oleh Bunga Amanda (2015) lontong yang diidentifikasi dalam penelitian ini diperoleh dari tiga titik atau kawasan pasar Kota Banda Aceh yaitu pasar Peunayong, pasar Setui dan pasar Ulee Kareng. Dari 9 sampel lontong yang diidentifikasikan menghasilkan, 4 sampel lontong teridentifikasi positif mengandung boraks dan 5 sampel lontong negatif mengandung boraks.

Para pedagang masih menggunakan bahan tambahan pangan (BTP) berupa boraks atau bleng karena bahan tersebut mudah didapatkan, pengetahuan pedagang mengenai bahan tambahan pangan (BTP) berbahaya masih rendah, dan pengawasan oleh dinas terkait belum dilaksanakan. Boraks atau bleng dapat membuat makanan menjadi menarik dan lebih awet sehingga pedagang akan merasa untung.

Gejala awal keracunan boraks bisa berlangsung beberapa jam hingga seminggu setelah mengonsumsi. Gejala klinis keracunan boraks biasanya ditandai dengan sakit perut sebelah atas (epigastrik), muntah, dan mencret; sakit kepala, gelisah; penyakit kulit berat (dermatitis); muka pucat dan kadang- kadang kulit kebiruan (cyanotis); hilangnya cairan dalam tubuh (dehidrasi), ditandai dengan kulit kering dan koma (pingsan); degenerasi lemak hati dan ginjal; otot-otot muka dan anggota badan bergetar diikuti dengan kejang- kejang; kadang-kadang tidak kencing (anuria) dan sakit kuning; tidak memiliki nafsu makan (anoreksia), diare ringan, dan sakit kepala (Cahyo Saparinto dan Diana Hidayati. 2006. h. 60-61).

Pasar Segamas Kabupaten Purbalingga adalah pasar tradisional terbesar di Purbalingga Pasar segamas menjual berbagai macam makanan yang menggunakan bahan tambahan pangan. Ketupat merupakan salah satu makanan yang menggunakan bahan tambahan pangan (BTP) berbahaya berupa boraks atau bleng.

Pasar Segamas terletak di gerbang kota sehingga banyak pedagang yang berjualan dan pembeli yang datang untuk membeli keperluan sehari-hari. Peneliti melakukan penelitian kandungan boraks pada 6 sampel ketupat janur dari pedagang yang membuat sendiri dan membeli dari orang lain.

Peneliti melakukan survei pendahuluan di Pasar Segamas Kabupaten Purbalingga pada bulan Oktober 2019 dan mengamati ketupat janur yang dijual di Pasar Segamas serta membeli 6 sampel ketupat janur dari berbagai pedagang yang ada di lokasi. Ketupat janur dibiarkan diruang terbuka dan digantung selama tiga hari. Dari 6 sampel tersebut terdapat didapatkan 4 sampel ketupat janur yang masih tetap kenyal, rasa masih enak dan beraroma khas ketupat. Sedangkan 2 sampel lagi sudah mengeluarkan air dari ketupat tersebut.

Pasar Segamas terletak di jalan Mayjend Sungkono Purbalingga yang memiliki luas 41.458 $\mathrm{m} 2$. Luas bangunan baik blok di dalam pasar maupun kantor $15.364 \mathrm{~m} 2$. Ditambah area parkir $3.149 \mathrm{~m} 2$ dan taman $1.035 \mathrm{~m} 2$ sehingga luas terbangun 19.854 m2. Masih ditambah area Rumah Pemotongan Hewan (RPH) unggas $1.182 \mathrm{~m} 2$.

Jumlah pedagang di Pasar Segamas sejumlah 1.689 pedagang. Jenis barang yang dijual di Pasar meliputi pedagang ketupat janur, pedagang hasil bumi, pedagang pakaian, pedagang kuliner, pedagang perlengkapan rumah tangga. Fasilitas yang dimiliki Pasar Segamas meliputi kios : 383 dan los : 656 .

Berdasarkan permasalahan latar belakang peneliti tertarik untuk melakukan penelitian tetang boraks pada ketupat janur. Yang bertempat di Pasar Segamas Kabupaten Purbalingga, sehingga peneliti mengambil judul "Identifikasi Boraks dalam Ketupat Janur di Pasar Segamas Kabupaten Purbalingga tahun 2020". Penelitian ini bertujuan untuk mengidentifikasi kandungan boraks pada ketupat janur yang dijual di Pasar Segamas Kabupaten Purbalingga berupa pemeriksaan secara organoleptik, pemeriksaan di laboratorium, deskripsi pengetahuan pedagang, deskripsi pengawasan dinas tertentu terkait dengan bahan tambahan pangan berbahaya. 


\section{Bahan dan Metode}

Subjek penelitian ini adalah ketupat janur yang dijual di Pasar Segamas Kabupaten Purbalingga berjumlah 6 (enam) sampel ketupat janur yang sudah siap dijual dari pedagang membuat sendiri dan pedagang yang membeli dari produsen.

Jenis penelitian ini termasuk jenis penelitian deskriptif, dengan tujuan untuk mengetahui ada tidaknya kadar boraks pada ketupat janur yang dijual di Pasar Segamas Kabupaten Purbalingga. Penelitian ini dilakukan dengan pengumpulan data di lapangan dan pemeriksaan di Laboratorium dan dibandingkan dengan Permenkes RI Nomor 033 Tahun 2012 tentang Bahan Tambahan Pangan.

Metode pengumpulan data yang dilakukan menggunakan:

a. Penelitian pendahuluan berupa pemeriksaan secara organoleptik meliputi indra peraba, indra perasa, indra penciuman, dan indra penglihatan. Melakukan perbandingan ketupat janur dari pedagang dan pengolahan sendiri ketupat janur dengan menerapkan metode yang sama kemudian dilakukan penilaian bau, rasa, warna dan tekstur dengan melibatkan 3 responden untuk melakukan pengecekan selama 3 hari pada sampel ketupat janur.

b. Pemeriksaan ketupat janur di Laboratorium Kesehatan Daerah Kabupaten Purbalingga dengan metode nyala api. Membandingkan hasil uji Laboratorium dengan Peraturan Menteri Kesehatan Republik Indonesia Nomor 033 Tahun 2012 tentang Bahan Tambahan Pangan.

c. Wawancara langsung pada pedagang ketupat janur dengan menggunakan kuesioner dan melakukan wawancara kepada petugas kesehatan lingkungan mengenai bahan tambahan pangan berbahaya pada makananan atau boraks.

\section{Hasil dan Pembahasan}

\section{Gambaran Umum}

Letak Geografis

Pasar Segamas terletak di Jalan Mayjend

Sungkono, Kelurahan Kalikabong, Kecamatan Kalimanah, Kabupaten Purbalingga. Luas wilayah Pasar Segamas $41.458 \mathrm{~m}^{2}$. Batas-batas Pasar Segamas sebagai berikut:

- Batas Timur : Jalan Mayjen Sungkono

- Batas Selatan : Hutan / taman kota

- Batas Barat : Persawahan

- Batas Utara : Pasar Hewan

Penelitian dilakukan di Pasar Segamas singkatan dari Segitiga Emas, diharapkan mampu meningkatkan aktifitas roda perekonomian di Kabupaten Purbalingga. Jumlah pedagang ketupat janur sebanyak 6 pedagang. 4 pedagang membuat sendiri dan 2 pedagang dari orang lain. Pedagang ketupat janur biasanya mulai berjualan mulai pukul 05.00 WIB sampai 09.00 WIB. Pasar menyediakan kebutuhan sehari-hari masyarakat dengan harga yang relatif murah dan terjangkau dengan cara tawar menawar.

\section{Gambaran Khusus}

\section{a. Pemeriksaan secara organoleptik}

Pemeriksaan secara organoleptik ciri-ciri ketupat janur yang dijual di Pasar Segamas Kabupaten Purbalingga. Pengamatan ini dilakukan oleh 3 panelis agar hasilnya lebih akurat dengan melihat 5 kriteria yang meliputi tekstur, rasa, aroma, penampilan dan tingkat keawetan lama waktu $3 \times 24$ jam.

Tabel 1

Hasil modus boraks secara organoleptik pada ketupat janur oleh seluruh panelis

\begin{tabular}{|c|c|c|c|c|c|c|}
\hline \multirow[b]{2}{*}{$\begin{array}{l}\mathbf{N} \\
\mathbf{o}\end{array}$} & \multirow[b]{2}{*}{ Sampel } & \multicolumn{5}{|c|}{$\begin{array}{c}\text { Ciri-ciri Fisik Ketupat Janur yang } \\
\text { Mengandung Boraks }\end{array}$} \\
\hline & & $\begin{array}{l}\text { Tek } \\
\text { stur }\end{array}$ & Rasa & $\begin{array}{c}\text { Aro } \\
\text { ma }\end{array}$ & $\begin{array}{c}\text { Pen } \\
\text { am } \\
\text { pila } \\
\text { n }\end{array}$ & $\begin{array}{c}\text { Daya } \\
\text { Taha } \\
\text { n }\end{array}$ \\
\hline 1 & $\begin{array}{c}\text { Ketupat } \\
1\end{array}$ & $\begin{array}{l}\text { Tdk } \\
\text { ken } \\
\text { yal }\end{array}$ & $\begin{array}{l}\text { Khas } \\
\text { ketup } \\
\text { at }\end{array}$ & $\begin{array}{l}\text { Khas } \\
\text { ketup } \\
\text { at }\end{array}$ & $\begin{array}{c}\text { Tid } \\
\text { ak } \\
\text { men } \\
\text { gkil } \\
\text { at }\end{array}$ & $\begin{array}{l}<3 \\
\text { hari }\end{array}$ \\
\hline 2 & $\begin{array}{c}\text { Ketupat } \\
2\end{array}$ & $\begin{array}{l}\text { Tdk } \\
\text { ken } \\
\text { yal }\end{array}$ & $\begin{array}{l}\text { Khas } \\
\text { ketup } \\
\text { at }\end{array}$ & $\begin{array}{l}\text { Khas } \\
\text { ketup } \\
\text { at }\end{array}$ & $\begin{array}{c}\text { Tid } \\
\text { ak } \\
\text { men } \\
\text { gkil } \\
\text { at }\end{array}$ & $\begin{array}{l}<3 \\
\text { hari }\end{array}$ \\
\hline 3 & $\begin{array}{c}\text { Ketupat } \\
3\end{array}$ & $\begin{array}{c}\text { Ken } \\
\text { yal }\end{array}$ & $\begin{array}{l}\text { Khas } \\
\text { ketup } \\
\text { at }\end{array}$ & $\begin{array}{l}\text { Khas } \\
\text { ketup } \\
\text { at }\end{array}$ & $\begin{array}{c}\text { Tid } \\
\text { ak } \\
\text { men } \\
\text { gkil } \\
\text { at }\end{array}$ & $\begin{array}{l}<3 \\
\text { hari }\end{array}$ \\
\hline 4 & $\begin{array}{c}\text { Ketupat } \\
4\end{array}$ & $\begin{array}{c}\text { Ken } \\
\text { yal }\end{array}$ & $\begin{array}{l}\text { Khas } \\
\text { ketup } \\
\text { at }\end{array}$ & $\begin{array}{l}\text { Khas } \\
\text { ketup } \\
\text { at }\end{array}$ & $\begin{array}{c}\text { Tid } \\
\text { ak } \\
\text { men } \\
\text { gkil } \\
\text { at }\end{array}$ & $\begin{array}{l}<3 \\
\text { hari }\end{array}$ \\
\hline 5 & $\begin{array}{c}\text { Ketupat } \\
5\end{array}$ & $\begin{array}{l}\text { Tdk } \\
\text { ken } \\
\text { yal }\end{array}$ & $\begin{array}{l}\text { Tdk } \\
\text { Khas }\end{array}$ & $\begin{array}{c}\text { Tida } \\
\mathrm{k} \\
\text { Khas }\end{array}$ & $\begin{array}{c}\text { Tid } \\
\text { ak } \\
\text { men } \\
\text { gkil } \\
\text { at }\end{array}$ & $\begin{array}{l}<3 \\
\text { hari }\end{array}$ \\
\hline 6 & $\begin{array}{c}\text { Ketupat } \\
6\end{array}$ & $\begin{array}{c}\text { Tid } \\
\text { ak } \\
\text { ken } \\
\text { yal } \\
\end{array}$ & $\begin{array}{l}\text { Khas } \\
\text { ketup } \\
\text { at }\end{array}$ & $\begin{array}{l}\text { Khas } \\
\text { ketup } \\
\text { at }\end{array}$ & $\begin{array}{l}\mathrm{Me} \\
\text { ngk } \\
\text { ilat }\end{array}$ & $\begin{array}{l}<3 \\
\text { hari }\end{array}$ \\
\hline
\end{tabular}

Berdasarkan tabel 1 didapatkan hasil pemeriksaan secara organoleptik sampel ketupat janur dari pasar Segamas Kabupaten Purbalingga sebanyak 6 sampel melibatkan 3 panelis dengan 5 
parameter yaitu tekstur, rasa, aroma, penampilan dan daya tahan menunjukkan secara fisik keseluruhan sampel dalam keadaan baik atau tidak menunjukkan terdapat boraks dalam ketupat janur tersebut.

Dhesy Dwi Susanti (2017) menjelaskan ciriciri ketupat yang mengandung boraks adalah teksturnya sangat kenyal. Hasil pengamatan yang dilakukan oleh panelis dapat diketahui dari segi tekstur sampel ketupat 3 dan 4 diduga terdapat boraks, karena memiliki tekstur kenyal dari sampel yang lain saat sampel di tekan langsung kembali ke bentuk semula.

Identifikasi bahan makanan tertentu yang mempunyai rasa khas, indra pengecap akan sangat berguna. Menurut Dhesy Dwi Susanti (2017) ciri-ciri ketupat mengandung boraks yaitu rasa seperti getir pada lidah setelah memakan. Untuk segi rasa ketupat yang tidak mengandung boraks adalah berasa khas ketupat, disini hasil perhitungan keseluruhan dari 3 panelis sampel ketupat 5 yang tidak berasa khas ketupat melainkan rasa sedikit busuk, dimungkinkan ketupat yang dijual adalah sisa dagangan ketupat kemarin.

Menurut Dhesy Dwi Susanti (2017) ciri-ciri ketupat mengandung boraks yaitu aroma mirip dengan aroma obat. Dari segi aroma, ketupat yang baik adalah ketupat memiliki aroma khas ketupat itu sendiri. Dari 6 sampel yang diuji secara organoleptik oleh 3 panelis didapatkan hasil sampel ketupat 5 yang tidak beraroma khas ketupat, melainkan berbau sedikit busuk. Mungkin ketupat yang dijual adalah sisa dagangan ketupat kemarin.

Menurut Dhesy Dwi Susanti (2017) ketupat yang mengandung boraks dari segi penampilan adalah mengkilat seperti kalis. Sampel ketupat 6 merupakan sampel yang tidak baik dari sisi penampilannya karena mengkilat dan diduga terdapat boraks didalamnya.

Parameter yang terakhir adalah daya tahan, yaitu ketupat didiamkan diruang terbuka selama $3 \times 24$ jam dengan posisi digantung dan amati sambil dirasakan ketupat tersebut sampai kapan ketupat tersebut tidak layak untuk dikonsumsi lagi. Dari 6 sampel yang diamati semuanya tidak layak untuk dikonsumsi lagi kurang dari 3x24 jam tepatnya hanya bertahan 2 hari karena ketupat sudah berubah tekstur, rasa, aroma dan penampilan.

\section{b. Pemeriksaan Ada Tidaknya Boraks}

Pemeriksaan ada tidaknya boraks dalam ketupat janur di Pasar Segamas Kabupaten Purbalingga. Sampel ketupat janur yang digunakan dalam penelitian ini sebanyak 6 sampel dari 6 pedagang yan diperoleh dari Pasar Segamas Kabupaten Purbalingga pada tanggal 16 April 2020 pukul 07.00 WIB. Sampel ketupat janur yang diambil kemudian diperiksa pada tanggal 16 April 2020 di Laboratorium Kesehatan Daerah Kabupaten
Purbalingga dengan metode nyala api. Jika nyala api berwarna hijau maka dinyatakan positif adanya boraks, tetapi jika nyala api berwarna biru maka sampel dikatakan negatif atau tidak mengandung boraks.

Tabel 2

Hasil pemeriksaan loboratorium boraks pada ketupat janur yang dijual

di Pasar Segamas Kabupaten Purbalingga

\begin{tabular}{ccc}
\hline No & $\begin{array}{c}\text { Kode } \\
\text { Sampel }\end{array}$ & $\begin{array}{c}\text { Hasil } \\
\text { Pemeriksaan }\end{array}$ \\
\hline 1 & Ketupat 1 & Negatif \\
2 & Ketupat 2 & Negatif \\
3 & Ketupat 3 & Negatif \\
4 & Ketupat 4 & Negatif \\
5 & Ketupat 5 & Negatif \\
6 & Ketupat 6 & Negatif \\
\hline
\end{tabular}

Berdasarkan tabel 2 dapat diketahui bahwa dari 6 sampel ketupat janur yang diambil pedagang ketupat di pasar Segamas diketahui negatif menggunakan boraks. Ketupat janur tersebut 4 sampel bikin sendiri dan 2 sampel dari produsen lain. Sesuai hasil tersebut, diketahui $100 \%$ sampel negatif menggunakan boraks.

Berdasarkan hasil Pemeriksaan Laboratorium Kesehatan Daerah Purbalingga dengan metode nyala api tanggal 16 April 2020 dengan jumlah 6 sampel ketupat janur menunjukkan hasil negatif. Boraks merupakan bahan tambahan berbahaya yang dilarang ditambahkan kedalam makanan. Hal tersebut telah diatur dalam Peraturan Menteri Kesehatan Republik Indonesia Nomor 033 Tahun 2012 tentang Bahan Tambahan Pangan yang menggolongkan boraks ke dalam jenis bahan berbahaya yang tidak diperbolehkan ditambahkan pada makanan.

Gangguan atau efek terhadap tubuh bila konsumen mengkonsumsi makanan yang mengandung boraks, tidak serta merta berakibat buruk terhadap kesehatan. Tetapi boraks yang sedikit demi sedikit tersebut diserap dalam tubuh konsumen secara kumulatif. Di sampan melalui saluran pencernaan, otak, hati dan testis (alat kelamin pria), dan kulit (George, 1965). Kalau dosisnya sudah tinggi biasa timbul pusing-pusing, muntah, diare, kram perut, bahkan kematian.

\section{c. Tingkat Pengetahuan Pedagang}

Tingkat pengetahuan pedagang pada pedagang ketupat janur yang ada di Pasar Segamas Kabupaten Purbalingga dilakukan dengan wawancara tentang boraks sebagai bahan tambahan makanan dan mengetahui ciri-ciri ketupat janur yang mengandung boraks. Pedagang diberikan 19 pertanyaan tentang boraks dan dinilai. 
Tabel 3

Hasil kuesioner tingkat pengetahuan pedagang ketupat janur di Pasar Segamas Kabupaten Purbalingga

\begin{tabular}{|c|c|c|c|c|}
\hline $\mathrm{N}$ & $\begin{array}{c}\text { Kode } \\
\text { Sampel }\end{array}$ & $\begin{array}{l}\mathrm{Ha} \\
\text { sil }\end{array}$ & $\begin{array}{l}\text { Kriteri } \\
\text { a } \\
\text { penilai } \\
\text { an }\end{array}$ & $\begin{array}{c}\text { Prese } \\
\text { ntase } \\
(\%)\end{array}$ \\
\hline 1 & $\begin{array}{c}\text { Ketupat } \\
1\end{array}$ & $\begin{array}{l}57 \\
\%\end{array}$ & $\begin{array}{l}\text { Tidak } \\
\text { Baik }\end{array}$ & $17 \%$ \\
\hline 2 & $\begin{array}{c}\text { Ketupat } \\
2\end{array}$ & $\begin{array}{l}78 \\
\%\end{array}$ & Baik & \\
\hline 3 & $\begin{array}{c}\text { Ketupat } \\
3\end{array}$ & $\begin{array}{l}73 \\
\%\end{array}$ & Baik & \\
\hline 4 & $\underset{4}{\text { Ketupat }}$ & $\begin{array}{l}68 \\
\%\end{array}$ & Baik & $83 \%$ \\
\hline 5 & $\begin{array}{c}\text { Ketupat } \\
5\end{array}$ & $\begin{array}{l}73 \\
\%\end{array}$ & Baik & \\
\hline 6 & $\begin{array}{c}\text { Ketupat } \\
6\end{array}$ & $\begin{array}{l}63 \\
\%\end{array}$ & Baik & \\
\hline
\end{tabular}

Berdasarkan tabel 3 dapat diketahui bahwa dari 6 pedagang ketupat janur, sebagian besar masuk kategori baik dengan nilai presentase $83 \%$. Sedangkan yang masuk kategori tidak baik hanya 17 $\%$. Umur responden paling muda yaitu 28 tahun dan tertua 60 tahun. Pendidikan responden yang paling banyak yaitu SD. Pengetahuan pedagang ketupat janur sudah mengerti tentang bahan tambahan makanan, jenis-jenis bahan tambahan makanan, manfaat dari bahan tambahan makanan, ciri-ciri makanan yang mengandung boraks dan persyaratan penggunaan bahan tambahan makanan.

Peningkatan pengetahuan pedagang tentang bahan tambahan makanan seperti bahan tambahan makanan yang diizinkan maupun yang tidak diizinkan dalam peraturan perundang-undangan yang tersebut telah diatur dalam Peraturan Menteri Kesehatan Republik Indonesia Nomor 033 Tahun 2012 tentang Bahan Tambahan Pangan. Dilakukan penyuluhan terkait dengan penggunaan bahan berbahaya boraks termasuk didalamnya ciri-ciri fisik ketupat janur yang menggunakan boraks.

Seseorang yang memiliki pendidikan rendah pengetahuannya terhadap bahaya boraks terbatas. Karena pengetahuannya tentang bahaya boraks terbatas maka sikapnya dalam penggunaan boraks tidak sesuai dengan yang dikehendaki dalam peraturan. Selanjutnya praktik yang dilakukan dalam pembuatan makanan juga tidak sesuai dengan yang dikehendaki dalam peraturan. Sebagai akibatnya terjadi pencemaran pada makanan jajanan yang dibuatnya (siti Istiqomah, 2016).

\section{d. Pengawasan Oleh Dinas tertentu}

Pengawasan oleh dinas tertentu terkait dengan bahan tambahan pangan berbahaya pada makanan di Pasar Segamas Kabupaten Purbalingga. Pemeriksaan dilakukan dengan wawancara langsung kepada petugas kesehatan lingkungan dari Puskesmas Kalimanah. Petugas kesehatan lingkungan diberikan 15 pertanyaan tentang pengawasan bahan tambahan pangan berbahaya.

Hasil pengawasan bahan tambahan pangan berbahaya di Pasar Segamas sebagai berikut :

1) Dinas yang mengawasi bahan tambahan pangan berbahaya pada makanan yaitu Puskesmas Kalimanah bekerjasama dengan Dinas Kesehatan Purbalingga dan Laboratorium Kesehatan Daerah Kabupaten Purbalingga.

2) Terdapat kegiatan uji pemeriksaan bahan tambahan pangan berbahaya pada makanan di Laboratorium Kesehatan Daerah Kabupaten Purbalingga. Petugas kesehatan lingkungan dari Puskesmas Kalimanah yang mengambil sampel makanan. Hasil uji pemeriksaan bahan tambahan pangan berbahaya akan keluar \pm 3 hari -4 hari. Dalam waktu satu tahun dilakukan saku kali pemeriksaaan saat akan lebaran Hari Raya Idul Fitri. Terakhir dilakukan pemeriksaan saat lebaran Hari raya Idul Fitri Tahun 2019.

3) Biaya yang digunakan untuk pemeriksaan bahan tambahan pangan berbahaya pada makanan dari anggaran bantuan operasional kesehatan (BOK) yang berasal dari kementerian kesehatan.

4) Dilakukan kegiatan analisis dan rekomendasi dari hasil pemeriksaaan laboratorium. Hasil pemeriksaan akan diberikan ke pihak Puskesmas Kalimanah kemudian dilaporkan ke Dinas Kesehatan Purbalingga selanjutnya laporan tersebut dikirim ke Dinas Kesehatan Provinsi Jawa Tengah.

5) Pada tahun 2018 pernah terbukti tahu yang mengandung formalin dan kerupuk gendar mengandung boraks.

6) Makanan yang sering diperiksa karena diduga menggunakan bahan pangan berbahaya bagi tubuh yaitu tahu, bakso kering, tempe, sosis. Petugas kesehatan lingkungan pernah mengambil sampel ketupat janur untuk menguji kandungan boraks.

7) Pihak pengawas bahan tambahan pangan akan memberi sanksi kepada pedagang yang terbukti menggunakan bahan tambahan pangan berbahaya. Tindakan pertama yang dilakukan yaitu mendatangi rumahnya kemudian diberi sanksi berupa peringatan awal. Selain itu yang bersangkutan membuat pertanyaan yang berisi bahwa tidak akan mengulanginya lagi. Dalam jangka seminggu dilakukan pengecekan selama tiga kali. Jika tahun depan diulangi lagi maka akan diproses hukum.

Berdasarkan hasil wawancara dengan pihak kesehatan lingkungan dapat diketahui pengawasan bahan tambahan pangan berbahaya di Pasar Segamas termasuk kategori sesuai Peraturan. Peraturan mengenai pengawasan bahan tambahan pangan berbahaya yaitu Peraturan Bersama Menteri Dalam 
Negeri Dan Kepala Badan Pengawas Obat Dan Makanan Republik Indonesia Nomor : 2 dan Nomor : 43 Tahun 2013 Tentang Pengawasan Bahan Berbahaya Yang Disalahgunakan Dalam Pangan. Berdasarkan Peraturan Bersama Menteri Dalam Negeri Dan Kepala Badan Pengawas Obat Dan Makanan Republik Indonesia Nomor : 2 dan Nomor : 43 Tahun 2013 Tentang Pengawasan Bahan Berbahaya Yang Disalahgunakan Dalam Pangan berisi ketentuan mengenai pengawasan bahan tambahan makanan diantaranya :

1) Salah satu bahan tambahan berbahaya yaitu boraks

2) Dibentuk keanggotaan tim pengawas dimulai dari pusat, provinsi, sampai kabupaten / kota.

3) Bupati / Walikota menyampaikan laporan pelaksanaan pengawasan bahan berbahaya dalam pangan kepada Gubernur dengan tembusan Kepala Balai Pengawas Obat dan Makanan dalam satu kali dalam setahun.

4) Pendanaan pengawasan pangan bersumber dari Anggaran Pendapatan dan Belanja Negara, Anggaran Pendapatan dan Belanja Daerah Provinsi atau Kabupaten / Kota.

5) Melakukan pengambilan contoh untuk uji laboratorium

6) Sanksi administrasi bagi usaha yang terbukti menggunakan bahan tambahan berbahaya pada makanan sebagai berikut :

- Peringatan tertulis

- Penghentian sementara kegiatan $\begin{array}{ll}\text { - } & \text { Rekomendasi pencabutan izin } \\ \text { - } & \text { Pencabutan izin usaha }\end{array}$

\section{Kesimpulan}

Berdasarkan penelitian identifikasi boraks pada ketupat janur yang dijual di Pasar Segamas Kabupaten Purbalingga, maka dapat disimpulkan sebagai berikut:

1) Hasil uji organoleptik sebanyak 6 sampel melibatkan 3 panelis dengan 5 parameter yaitu tekstur, rasa, aroma, penampilan dan daya tahan menunjukkan secara fisik keseluruhan sampel dalam keadaan baik atau tidak menunjukkan terdapat boraks dalam ketupat janur tersebut.

2) Sampel yang dilakukan penelitian berjumlah 6 ketupat janur dan dilakukan uji laboratorium menunjukkan hasil $100 \%$ sampel tersebut bebas dari boraks dan aman untuk dikonsumsi masyarakat.

3) Tingkat pengetahuan yang dimiliki oleh 6 pedagang ketupat janur sebagian besar adalah baik dengan nilai persentase $83 \%$ dan $17 \%$ dalam kategori tidak baik.

4) Pengawasan bahan tambahan pangan berbahaya oleh dinas tertentu termasuk kategori sesuai Peraturan Bersama Menteri Dalam Negeri Dan Kepala Badan Pengawas Obat Dan Makanan Republik Indonesia Nomor : 2 dan Nomor : 43 Tahun 2013 Tentang Pengawasan Bahan Berbahaya Yang Disalahgunakan Dalam Pangan.

\section{Daftar Pustaka}

Achmad Djaeni Sediaoetama. 1993. Ilmu Gizi Untuk Mahasiswa dan Profesi Di Indonesia. Jakarta: PT Dian Rakyat

Aliza Dapur. 2010. Hidangan Ketupat Nusantara yang Paling Laku Dijual. Jakarta: PT Gramedia Pustaka Utama

Bunga Amanda. 2015. Identifikasi Boraks pada Lontong yang Dijual Di Wilayah Kota Banda Aceh. Skripsi, Banda Aceh: Universitas Syiah Kuala Darussalam Fakultas Keguruan dan Ilmu Pendidikan Program Studi Pendidikan Kesejahteraan Keluarga

Cahyo Saparinto dan Diana Hidayati. 2006. Bahan Tambahan Pangan. Yogyakarta: Kanisius.

Dantjet T. Sembel. 2015. Toksikologi Lingkungan Dampak Pencemaran Dari Berbagai Bahan kimia Dalam Kehidupan sehari-hari. Yogyakarta: CV. Andi Offset

Departemen Kesehatan RI. 1998. Pedoman Pembinaan dan Pengawasan Sanitasi Makanan Jakarta: Ditjen PPM \& PLP
Desty Ervira Puspaningtyas. 2014. Enak Sih Tapi.... Jakarta Selatan: F Media

Dhesy Dwi Susanti. 2017. Sanitarian Puskesmas Bojongsari

F.G. Winarno dan Titi Sulistyowati Rahyu. 1994. bahan tambahan untuk makanan dan kontaminan. Jakarta: Pustaka Sinar Harapan

Fitri Ariyani. 2016. Studi Boraks Pada MI Basah yang Dijual Di Pasar Cerme Desa Purwosari Kecamatan Baturraden Kabupaten banyumas Tahun 2016. Karya Tulis Ilmiah. Purwokerto: Kesehatan RI Politeknik Kesehatan Semarang Jurusan Kesehatan Lingkungan Purwokerto

George, A.J. 1965. Toxicity of boric acid through skin and mucous membrane. Food Cosmet. Toxicol. 3:99-101

Hasan Ismail. 2017. Identifikasi Boraks Dalam Kupat Janur Di Pasar Cerme Kelurahan Purwosari Kecamatan Baturraden Kabupaten Banyumas Tahun 2017. Karya Tulis Ilmiah. Purwokerto: Kesehatan RI Politeknik Kesehatan Semarang Jurusan Kesehatan Lingkungan Purwokerto 
Ida Mudzakirah. 2016. Identifikasi Penggunaan Zat Pengawet Boraks dan Formalin Pada Makanan Jajanan Di Kantin UIN Alauddin makasar. Skripsi. Makassar: Fakultas Kedokteran dan Ilmu kesehatan Universitas Islam Negeri Alauddin Makassar

Misyka Nadiratul Haq. 2014. Analisis Faktor Resiko Pencemaran Bahan Toksik Boraks Pada Bakso Di Kelurahan Ciputat Tahun 2014. Skripsi. Jakarta: Universitas Islam Negeri Syarif hidayatullah Fakultas Kedokteran dan ilmu kesehatan Program Studi Kesehatan Masyarakat

Nur Rohimah Fuad. 2014. Identifikasi Kandungan Boraks Pada Tahu Pasar Tradisional Di Daerah Ciputat. Skripsi. Jakarta: Fakultas kedokteran dan Ilmu kesehatan UIN Syarif Hidayatullah Program Studi Pendidikan Dokter

Nurheti Yuliarti. 2007. Awas bahaya di balik lezatnya makanan. Yogyakarta: Andi Offset

Nursanti Riandini. 2008. Bahan Kimia dalam Makanan dan Minuman. Bandung: Shakti Adiluhung

Peraturan Daerah Kota Bandung. 2009. Nomor 02 Tahun 2009 Tentang Penataan Pasar Tradisional. Pusat Perbelanjaan Dan Toko Modern

Rahmawati, R. 2012. Bahan Tambahan Makanan yang Berbahaya posted 20 oktober 2012. http://renyrahmawatilubisreanerel_fk12.web. unair.ac.id/artikel_detail-61903-UmumBahan\%20Tambahan\%20Makanan\%20yang \%20Berbahaya.html

Republik Indonesia. Peraturan Bersama Menteri Dalam Negeri Dan Kepala Badan Pengawas Obat Dan Makanan. 2013. Nomor 2 dan Nomor 43 Tahun 2013 Tentang Pengawasan Bahan Berbahaya Yang Disalahgunakan Dalam Pangan
Republik Indonesia. Peraturan Menteri Kesehatan. 2012. Nomor 033 Tahun 2012 Tentang Bahan Pangan

Riski Amelia. 2014. Identifikasi dan Penentuan Kadar Boraks dalam Lontong dijual di Pasar Raya Padang. Padang: Universitas Andalas Padang Fakultas Kedokteran

Salam N Aritonang. 2010. Susu Dan Teknologi. Yogyakarta: Swagati Press

Siti Istiqomah. 2016. karakteristik, Pengetahuan, Sikap, Dan Praktik Dagang Bakso Terhadap Penambahan Boraks Dalam Bakso Di Kota Bengkulu. Tesis, Bogor: Sekolah Pascasarjana Institut Pertanian Bogor

SNI 01-2346-2006 Petunjuk Pengujian Organoleptik dan atau Sensori

Sub Direktorat Sanitasi Makanan dan Bahan Pangan Direktorat Penyehatan Lingkungan Direktorat Jenderal PPM \& PL Departemen Kesehatan RI. 2006. Kumpulan Modul Kursus Hygiene sanitasi Makanan \& Minuman, Jakarta: Bakti Husada

Tri Cahyono. 2020. Panduan Penulisan Tugas Akhir. Purwokerto: Kementerian Kesehatan RI Politeknik Kesehatan Kemenkes Semarang Jurusan Kesehatan Lingkungan

Ummi Salamah Lubis. 2015. Analisis Kandungan Boraks Pada lontong Serta Pengetahuan dan sikap Pedagang tentang Boraks di Kelurahan AEK Tampang Kota Kota Padang Sidimpuan Tahun 2015. Skripsi. Medan: Universitas Sumatera Utara Fakultas Kesehatan Masyarakat

Wahono. dkk. 2011. Siap Menghadapi UN SMP/MTs 2011. Jakarta: Grasindo a Punya Cerita. Jakarta: Cerdas Interaktif (penebar Swadaya Group)

Yuyun A dan Delli Gunarsa. 2011. Cerdas Mengemas Produk Makanan dan Minuman. Jakarta Selatan: PT AgroMedia Pustaka 